\title{
Images of Protest in Social Media for the Virtual Community
}

\author{
Eleanor Lisney \\ Birmingham City University \\ Millennium Point, Curzon Street \\ Birmingham B4 7XG, UK \\ Eleanor.Lisney@mail.bcu.ac.uk
}

\author{
Kirsten Forkert \\ Birmingham City University \\ Millennium Point, Curzon Street \\ Birmingham B4 7XG, UK \\ Kirsten.Forkert@bcu.ac.uk
}

\section{INTRODUCTION}

This exhibition is a collation of images, videos and photographs used in social media for the protest movements in the UK, with a focus on disabled people, during this era of austerity. It shows the importance of citizen journalism when mainstream journalism is said to have ignored the voices of disabled people engaging in protests. This is a look back into the protests held in the last five years of Conservative Lib Dem Coalition government from 2010.

\section{A NEW COLLABORATION FOR DISABLED AND TRADE UNIONS IN PROTESTS AGAINST THE COALITION GOVERNMENT}

Disabled people led the protest on October 3rd 2010 against the Tory cuts. The demonstration was backed by three trade unions - the PCS, NUJ and UCU - as well as local trade bodies and other groups, and organised by the Right to Work Campaign.

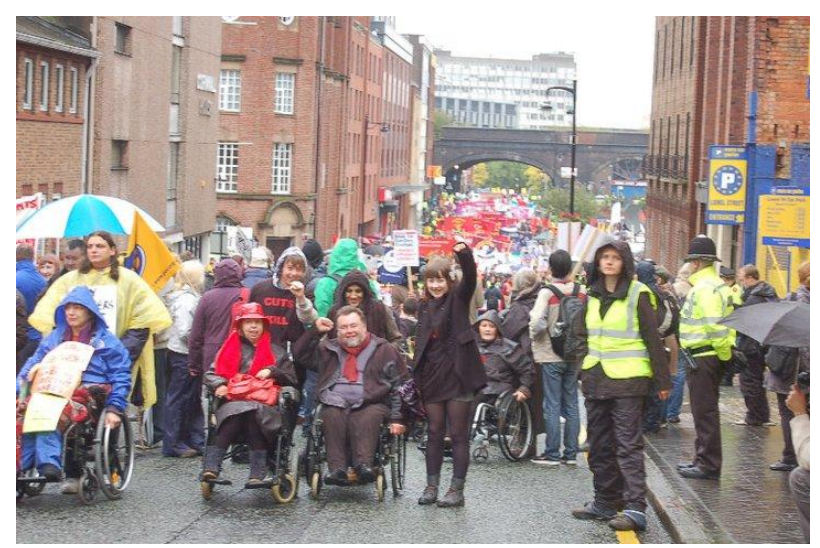

Figure 1: Disabled people lead the protest, the first of many, in Birmingham (Photo from DPAC)
This is the start of many such protests and direct actions as the cuts and austerity drive began to bite.

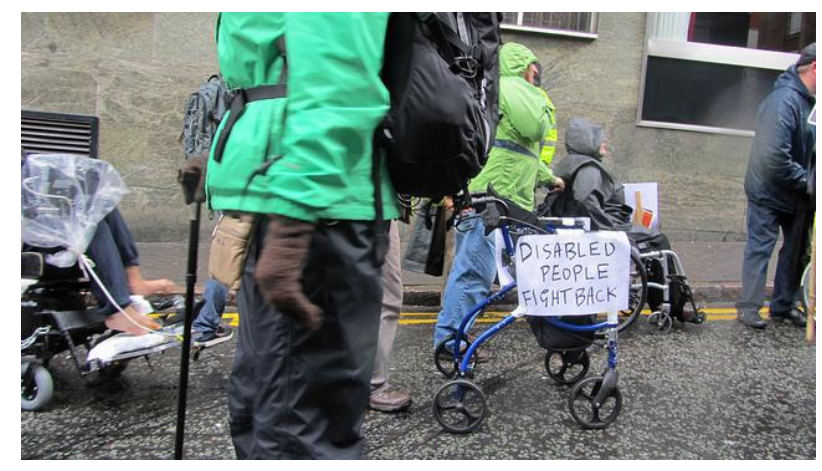

Figure 2: Disabled people fight back (Photo from DPAC)

\subsection{Direct actions on the streets of London}

As it became clear that the pressure of austerity is increasing its impacts on disabled people, the campaigning disabled group, Disabled People Against Cuts took to the streets on direct actions to bring publicity to the cuts.

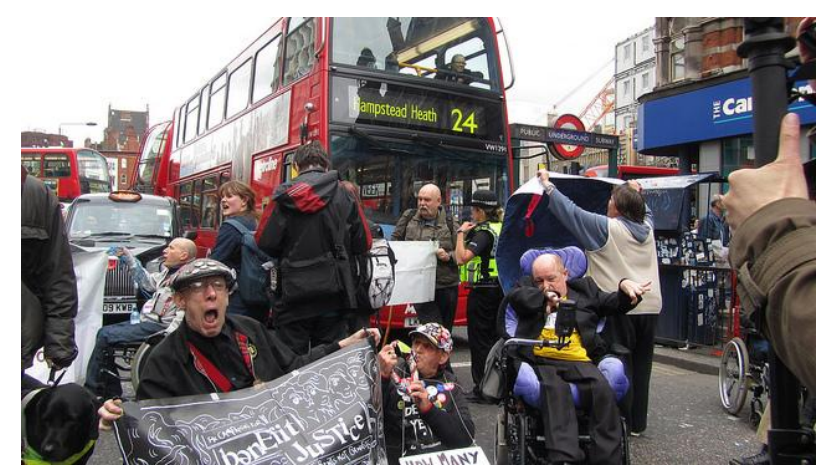

Figure 3: Blocking traffic at Oxford Street (Photo from DPAC)

However, tabloid media continued the 'scrounger' rhetoric of disabled people leading to a protest 
outside the Daily Mail offices. These media reports were said to lead to an increased amount of disability hate crimes. Inclusion London commissioned the Glasgow Media Group and the Strathclyde Centre for Disability Research to carry out a study to analyse changes in the way the media are reporting disability and how it has impacted on public attitudes towards disabled people entitled Bad News for Disabled People: How the newspapers are reporting disability.

Disabled people started to have their own photographers and media followers who tweeted and add their own versions of events filling in the gaps where the mainstream ignored. Photos were being taken by Demotix photo journalists such as Pete Riches and Howard Jones. Kate Belgrave started to document disabled people at Job centres who were being coerced and sanctioned.

Disabled people were getting better with their allies in the media output and using the visual impact to drive their message across. Many of the direct actions were being live-streamed by Occupy London, 'Obi' Abadinas, such as the occupation of the lawn at Westminster Abbey against the closure of the Independent Living Fund that supports severely disabled for independent living. There was the iconic 10,000 Cuts and Counting on 28 September 2013, organised by Occupy London and Disabled People against Cuts where Parliament Square was strewn with white flowers in memory of those who have died and those still suffering as a result of the Government's austerity drive.
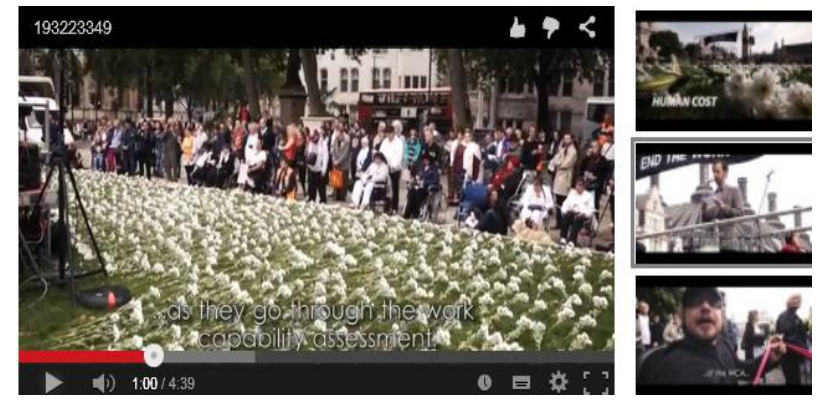

Figure 4: Screenshot of Short film: Human Cost by F. Gonzales of the 10,000 cuts 2013 at Parliament Square (https://vimeo.com/75673397)

It is not just about austerity that disabled people gathered and gave their views. One of the most visual impacts outside the House of Lord was for the Assisted Dying Bill. Under the banner of Not Dead Yet, disabled and allied protestors demonstrated against Lord Falconer's Bill against adults who are terminally ill to be provided at their request with specified assistance to end their own life; and for connected purposes. Disabled people say that it is a slippery slope where disabled people could be coerced to euthanasia because of the perception of society that their lives lack a certain quality of life, therefore, they would prefer death. The sight of protestors outside helped those fighting against it in the House of Lords such as Baroness Jane Campbell and Tanni GreyThompson.

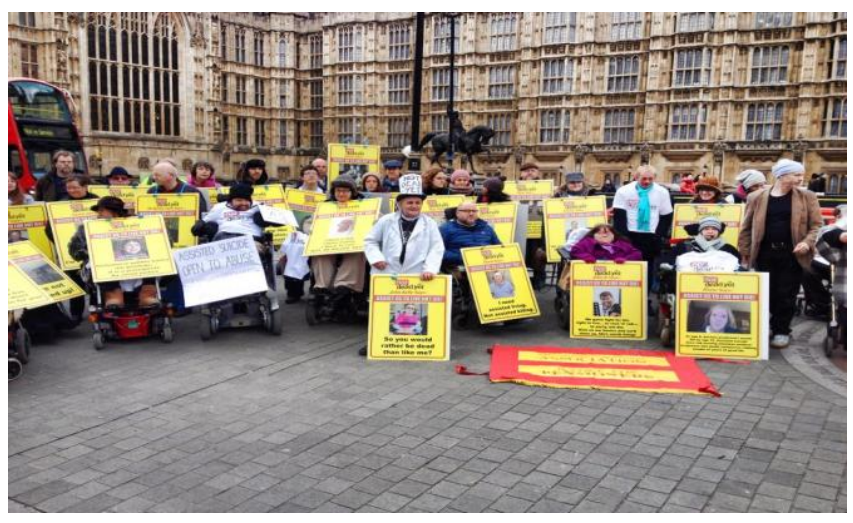

Figure 5: Group photo of disabled protestors outside House of Lords (Photo by Jo Church)

\section{REFERENCES}

Bellows, A. (2015) The Daily Mail \& Disability. http://realmedia.press/2015/03/21/the-daily-maildisability/ (retrieved 22 March 2015).

DPAC (2010) Disabled people led the protest on October 3rd against the Tory cuts. Disabled People Against Cuts (4 October) https://disabledpeopleprotest.wordpress.com/2010/ 10/04/174/ (retrieved 16 March 2015).

Pring, J. (2011) Protesters call on Daily Mail to 'stop the lies' about benefits claimants (4 April) http://www.disabilitynewsservice.com/protesterscall-on-daily-mail-to-stop-the-lies-about-benefitsclaimants/ (retrieved 18 March 2015).

Strathclyde Centre for Disability Research and Glasgow Media Unit (2011) Bad News for Disabled People: How the newspapers are reporting disability. In association with Inclusion London (October).

McConnell, F., \& Walker, P. (2014) Assisted Dying Bill debated in the House of Lords. The Guardian (18 July)

http://www.theguardian.com/society/2014/jul/18/ass isted-dying-bill-debate-live-updates (retrieved 18 March 2015).

Wynne Jones, R. (2013)10,000 Cuts and Counting: Protest campaign in memory of victims of welfare reforms. The Daily Mail (18 September)

http://www.mirror.co.uk/news/uk-news/10000-cutscounting-campaign-memory-2281143 (retrieved 18 March 2015). 